\title{
An Impact Assessment of the Nigerian Power Sector Reforms
}

\author{
Wara, S.T. ${ }^{a}$, Abayomi-Alli, A. ${ }^{b}$, Umo, N.D., Oghogho, I. ${ }^{c}$ and Odikayor, C.D. ${ }^{d}$
}

Product Development / Energy Centre, Department of Electrical and Computer Engineering, General Abdulsalami A. Abubakar College of Engineering, Igbinedion University Okada, Edo State, Nigeria

a email: docwarati@yahoo.com, ${ }^{\text {b }}$ abayomialli_adebayo@yahoo.com, coghoghoik@yahoo.com, dickinsodika@yahoo.com

\section{Keywords: Electricity, PHCN, Deregulation, Power sector, Reforms}

\begin{abstract}
This paper examines the various reforms carried out in the Nigerian power sector between the year 1999 and 2007 and its impact on the life of the average citizens. Efforts were made to review relevant literatures, questionnaires were administered and forty-nine responses were received and the result was analyzed through the use of simple percentages and correlation coefficient. The correlation coefficient method, $r$ (the product moment of the correlation was negative and of magnitude -1, implying a perfect correlation in the negative direction (deregulations and reforms are not improving the power sector of Nigeria yet). The research hypothesis, $\mathrm{H}_{\mathrm{R}}$, stated that the deregulation and reforms did not evidently improve the power sector. It was recommended that the government should continue the rehabilitation of the various power systems in a guided manner to allow a core Nigerian investor, consider alternative sources of energy like solar, tide, biomass, wind.
\end{abstract}

\section{Introduction}

Within the particular conception of socio-economic processes which underscore every economic system, economic development, globally, revolves around the issues of the character, structure, pattern and evolution of desirable inter-personal relations of production, allocation and utilization of available resources in any country. To optimally develop and efficiently manage such available resources, as well as equitably allocating and effectively utilizing them and subsequently putting economic development firmly on course, modern operational technologies with respect to production, allocation and utilization are designed and tied strictly to the use of energy in one form or the other. Thus, the quest to rapidly and firmly put Nigeria on the course of economic development is, technically, a function of adequate supply and distribution of energy, particularly electricity.

In this regard, adequate supply and distribution of electricity constitute a central development issue which cannot be over-emphasized. Apart from serving as the pillar of wealth creation in Nigeria, it is also the nucleus of operation and subsequently the 'engine of growth' for all sectors of the economy. In recognition of the consolidating linkages between the energy sector and other sectors of the economy, electricity development and utilization therefore have pervasive impacts on a range of socio-economic activities and consequently the living standards of citizens in the country.

The foregoing assertions subsequently explain why one of the most frustrating and disturbing economic development issues in the Nigerian economy and society, particularly since the 1960s, is that of inadequacy of electricity supply and distribution. The situation of the emerging electricity outages from the supply inadequacy, especially one year before the inception of the Obasanjo ledcivilian administration on May 29, 1999, was that of persistent electric power outages at alarming frequencies, in the face of abundant primary electricity resources-coal, natural gas, geothermal, tide, solar, biogas, biomass $[1,2]$. 
Incidentally, some analysts have defined this period as a period of serious electricity crisis, a crucial or decisive movement, an undesirable turning point, a time of difficulty and distress; a state of confusion when things no longer happen in the normal or usual manner.

Government recognized the inadequacy of this supply and thus noted the cardinal challenge therein. In this regard, the new civilian administration identified for the millennium the need to create a socio-economic environment that does not suffer the inadequacy of the past. Thus, the overriding task of government at the time was a single minded pursuit of growth and development which would go beyond the annual budgetary revenue and expenditure allocation to the electricity sector. Towards this end, Government released the 1999-2003 Economic Policy document which sets out very clearly its stretching goals in which 14 specific quantifiable target areas featured. Against this background, a framework was proposed for taking government out of direct involvement in most economic activities which are best suited for private sector undertaking such as energy and power generation as well as Provide the enabling legal, fiscal and monetary environment for the private sector to become the effective engine of growth and development in the economy, and, Up-grade the performance of major infrastructural (electricity) facilities.

According to government, the foregoing is required to open new and sustainable economic opportunities to all Nigerians for the pursuit of honest and fulfilled life. However, in order to attain these stated objectives, some strategies were designed. Such strategies include among several others:

-The privatization of NEPA under the guided privatization program which was anticipated to begin in 2000 with the establishment of a regulatory framework followed by drawing up modalities for effective private sector participation.

-Reduction of tariff in favour of imported raw materials and the rehabilitation and resuscitation of infrastructural facilities to encourage increased capacity utilization and increased budgetary allocation, particularly to, among others, the energy (electricity) sector. It also promised to stamp out the phenomenon of shortages of petroleum products and greatly improve the performance of major infrastructural facilities especially by reducing the frequency of power outages across the nation in order to make development objectives attainable.

\section{Data Analysis}

Both primary and secondary sources of data were utilized. This necessitated the extensive use of questionnaires, adoption of personal interviews and observational techniques including the use of library services. The questionnaire seeks answers to some basic electricity management methods, processes and problems. Respondents to questionnaire are required to cite some problems and suggest ways of solving these problems of the power/electricity generation.

\section{Method of Data Analysis}

The data collected was edited, coded, analyzed and summarized in tabular forms. Simple percentages were used to indicate the composition of respondents in the population with specific responses to given questions in the questionnaire. In testing the hypothesis, correlation coefficient was used. This helped to test whether the null hypothesis should be accepted or rejected. Forty nine copies of the questionnaire were duly completed and returned representing $97 \%$ of total copies returned. The data analyses were conducted as shown on Table 1 below. 
Table 1: Showing the Analysis of the Questions from the Questionnaires.

\begin{tabular}{|l|l|l|l|l|l|}
\hline S/n & Analysis of Question & Yes & \% & No & \% \\
\hline 1 & Reforms and Deregulation Impact & 13 & 26.53 & 36 & 73.47 \\
\hline 2 & Lives and Businesses of Nigerians & 9 & 18.37 & 40 & 81.63 \\
\hline 3 & Efficiency and Effectiveness & 9 & 18.37 & 40 & 81.63 \\
\hline 4 & Growth, Progress, and Development & 47 & 95.92 & 2 & 4.08 \\
\hline 5 & Necessity of Reforms & 38 & 22.45 & 11 & 77.55 \\
\hline 6 & Electronic Billing System & 10 & 20.41 & 39 & 79.59 \\
\hline 7 & Generating More Revenue & 48 & 97.96 & 1 & 2.04 \\
\hline 8 & Affordability of New Billing System & 25 & 51.02 & 24 & 48.98 \\
\hline 9 & PHCN as a Growing Concern & 4 & 8.16 & 45 & 91.83 \\
\hline 10 & Improvement & 36 & 73.47 & 13 & 26.53 \\
\hline 11 & 10,00MW by the End of 2007 & 12 & 24.49 & 37 & 75.51 \\
\hline & Analysis of Question & Relevant & $\mathbf{\%}$ & Irrelevant & $\mathbf{\%}$ \\
\hline 12 & Relevance of Reforms and Deregulation & 49 & 100 & 0 & 0 \\
\hline & Analysis of Question & Poor & $\mathbf{\%}$ & Average & $\mathbf{\%}$ \\
\hline 13 & Availability of Electricity Supply & 33 & 67.35 & 16 & 32.65 \\
\hline
\end{tabular}

\section{Testing Of Hypothesis}

The hypothesis set for the study is tested using Correlation Coefficient. Coefficient (the product moment of the correlation). The data got from the questionnaire administered will be used:

Where $\quad r=\frac{N \Sigma X Y-\Sigma X \Sigma Y}{\sqrt{ }\left[N \Sigma X^{2}-(\Sigma X)^{2}\right]\left[N \Sigma Y^{2}-(\Sigma Y)^{2}\right]}$

Where $\quad \mathrm{r}=$ product moment of correlation coefficient

$\mathrm{N}=$ number of questions $=13$

$\mathrm{X}=$ Yes responses

$\mathrm{Y}=$ No responses

$\Sigma=$ summation

The result of the correlation coefficient ' $r$ ' will be subjected to (t)-test.

$$
(\mathrm{t}) \text {-test is given as } \quad 1-\mathrm{r} \sqrt{ }\left(\mathrm{N}-2 / \mathrm{r}^{2}\right)
$$

Where $\quad \mathrm{N}=$ number of questions $=15$

$\mathrm{r}=$ product moment of correlation coefficient

$t=$ test of hypothesis

\section{Hypothesis}

$\mathrm{H}_{\mathrm{O}}$ : Deregulation and reform is improving the power sector of Nigeria.

$\mathrm{H}_{\mathrm{R}}$ : Deregulation and reform is not improving the power sector of Nigeria.

By doing the Analysis of Yes and No Responses in the questionnaire as shown in Table 1, we obtain the following $\quad \sum X=316, \sum Y=321, \sum X Y=4358, \Sigma X^{2}=11126, \Sigma Y^{2}=11371,(\Sigma X)^{2}=$ 99856

$(\Sigma \mathrm{Y})^{2}=103041$

Inserting the values into Eq. 1 we have $r=-1$

The analysis of the hypothesis shows that there is a perfect correlation in the negative direction, i.e. responses show that deregulation and reform are not improving the power sector of Nigeria yet, and inserting values into Eq. 2, we obtain the calculated value of $(\mathrm{t})=6.633$ where the Degree of freedom is $\mathrm{N}-2$, i.e. $13-2=11$ and the Critical value at 0.05 level of significance $=2.20(\mathrm{t}-$ tabulated).

Since the tabulated value of $(t)$ is less at 2.20 than the calculated value of $(t)$ at 6.633 , therefore, we reject the null hypothesis $\left(\mathrm{H}_{\mathrm{O}}\right)$ and accept the research hypothesis $\left(\mathrm{H}_{\mathrm{R}}\right)$. 
From the analysis done in this section we draw a conclusion on the hypothesis tested that deregulation and reform have not improved the power sector of Nigeria yet in a way that will affect the supply of electricity to citizens, improve the economic and financial standing of the country, improve in industrialization, reduce the inflation rate, and affect individual businesses positively. Therefore, the non existence of any improvement in the power sector may lead to a total collapse of the power sector which also means that the country will be in darkness, high inflation rate, economic failure, un-civilization, increased crime rate, and corruption.

\section{Reform of the Nigerian Power Sector}

The Nigerian power sector before the 1999 was, to say the least, in a deplorable state. Only 15 out of 79 generating units installed were operational in 1999 with a generation capacity of only $1,520 \mathrm{MW}$ and the severe outages crippling the economy, no new power station was been built in over 10 years before 1999 and there had been no major overhaul of the existing power infrastructure in 19 years prior to 1999 [3]. With the last transmission line built in 1987, the power transmission infrastructure was weak while the epileptic distribution network was incapable of providing a satisfactory level of service to consumers.

While the government clearly understood that massive investment in all the three tiers of the electricity industry was necessary, a holistic approach was essential in tackling the problem. The first few years were therefore utilized in system studies, planning and preliminary engineering designs. The rehabilitation of existing facilities, as a transitional initiative, raised generation capacity to about $3,000 \mathrm{MW}$ by the year 2003 [4]. This effort was to provide some relief to consumers, because new power plants take several years to come on stream. For example, by August 2003, the following measurable targets, among many others, were set by the government towards the establishment of a sustainable electric power industry:

-Generate 10,000MW by the end of 2007 from existing power plants, new facilities and Independent Power Producers (IPP).

-Develop the capacity to reliably transmit and distribute the increased generation.

-Develop a medium term investment plan to 2010 for the sector.

-Reform the power sector to allow for private sector participation and increased efficiency.

-Exceed the Millennium Development Goals (MDG) target of access to electricity.

This unprecedented growth in power infrastructure evolved into the aptly named National Integrated Power Projects (NIPP), under which a sum of US\$2.5 billion was expended.

\section{National Integrated Power Project (NIPP): Catalyst For Sustainable Power Supply}

Through the power policy of 2001 and the EPSR Act 2005, the Obasanjo Administration had initiated and was committed to a comprehensive power reform program to restructure, privatize and liberalize the sector. This blueprint aims at ultimately closing the huge supply/demand gap and in the short run would rely mainly on public sector generation projects with only a few private sector initiatives, but in a medium to long term the entire sector would be private sector driven under the new Public Private Partnerships (PPP) model. While other countries were busy increasing their power generation capacity, Nigerian Government was either under-funding the sector or outrightly neglected to fund it. Out of Africa's three largest economies, Nigeria is the most underdeveloped. South Africa's 40 million people enjoy 40,000MW of electricity, while 75 million Egyptians have access to 20,000MW of electricity [4]. In contrasts Nigeria's 125 million people, a population larger than both Egypt's and South Africa's combined share a miserly 1700MW. This appalling score card has put electricity supply in the front burner as the most critical of all Nigeria's infrastructural needs. It underscores the crucial significance of the Electric Power Sector Reform (EPSR) 2005 legislation, deregulating the power sector and opening up the space for competition by private generating companies, power distributions and allied industries.

The Federal Government has already taken quantum leap in addressing the decay in the nation's power sector by resuscitating through the provision of new host capacity, expansion of Independent 
Power Producers (IPP) and Emergency Power Producers (EPP) as well as improved funding to the tune of N170 billion in capital allocation since 1999. World Bank financial assistance for the sector came through multilateral and bilateral grants and credit facilities to the tune of $\$ 100$ million IDA credit. The 2001 Power Policy and EPSR Act 2005 reform blue print set the stage for the unbundling of NEPA into 18 semi-autonomous (11 distribution, 1 transmission and 6 generation companies) controlled by the Power Holding Company of Nigeria (PHCN) [5]. Each business unit operates like a private company with efficiency, competition, and profit motive. Eventually, NEPA's successor company (PHCN) as a transitional enterprise is expected to be eased out or be privatized into private ventures. To demonstrate its commitment in providing a road map for the power sector, the Federal Government has set a generation target of 10,000MW capacity by the end of 2007. In marching its ambitious reform with action, government marshaled out a comprehensive plan to increase power generation and overhaul the entire power system with focus on delivery. In 2001 two new power stations Afam V and Delta II providing 426MW were commissioned and the 300MW IPP AES Barge. In 2005, the Agip IPP added 480MW. It also rehabilitated units of various existing power stations [6].

Under the arrangement with Chinese partnership, the government funded new electricity generation stations in Omotosho (335MW), Geregu (414MW), Papalanto (335MW), Alaoji (346MW) and Delta III (150MW). Also the Rural Electrification Agency of Nigeria (REA) has been put in place to promote and provide financial and technical assistance to various operators in the rural areas. At the regulatory level, government has established the National Electric Regulatory Commission (NERC) to oversee and ensure that operators comply with the operation laws and standard codes.

\section{Conclusion}

Findings, in this work, have confirmed that privatization of PHCN has not yet had the desired effect on efficiency of the Nigerian power sector. There are still power outages as reflected in the responses from the respondents as electricity power supply can be said to have improved despite the reforms in the last eight years. While this study identified certain factors militating against the smooth running of the power sector, the study however concludes that if proper attention is not paid to these issues, the possibility of PHCN making that mark of generating $10,000 \mathrm{MW}$ at the end of 2007 and giving stable uninterrupted light to all Nigerians will not be achieved in the end.

\section{Recommendations}

Deregulating the power sector was meant to improve the power sector, improve the nation's economy and also better the lives of the Nigerian citizens. Based on the findings of this paper, it has not achieved that yet. Below are a few recommendations that if carefully studied and utilized would make a great difference in the power sector and speed off the power sector reform program currently going on. The recommendations are as follows:

Under the guided privatization program which takes the form of 40:40:20 percent equity share holding structure for government, foreigners and indigenes respectively, government should prevent the transfer of public monopoly to private monopoly. In this regard, the application of a competing market structure under which some firms based on the market structure and size should be allowed to operate and compete in output, quality and tariffs.

Electricity development activities should not only be deregulated; they should also be liberalized. This would allow new firms (local and foreign) to go into electricity business and compete with the central body in whatever form it is privatized in the long run.

The execution of the reform program with regard to electricity development is too slow for any effective impact. Government should therefore, pronounce the deregulation and liberalization of electricity production and subsequently approve the applications of would be producers in Nigeria. There is also the need to increase the transmission capacity of the nation. It is one thing to increase the generation capacity and another to increase its transmission capabilities. If the transmission 
capabilities cannot carry the generation capacity, then, there would be a failure in the whole plan for sustainable power supply. Additionally, states and local firms that are desirous of going into electricity business should be actively encouraged by the government. Government is also advised to consider its $40 \%$ equity shareholding in PHCN as transitory. The ultimate intention should be to also look for a Nigerian core investor that would hold at least $30 \%$ of government shares while the remaining $10 \%$ can be sold to interested Nigerian small holders. It is believed that except a Nigerian core investor is involved in electricity development, there could be the risk of excessive domination by foreigners who could eventually swindle the Nigerian government and the numerous small shareholders. There is also the need to explore other alternative sources of energy, such as, solar, tide, biomass, wind, etc. This is to remove the countries focus on only oil, hydro and gas for generation of electricity. This other alternative sources of energy have proven very effective if properly utilized.

If these recommendations are effectively and efficiently implemented the plan to give all Nigerians stable electricity supply will be achieved optimally and the economy of the country will record a tremendous change. Even if the10,000MW mark is not met by the end of 2007, it can be achieved significantly the following year, if these recommendations are adhered to.

The issue is not only to put the power sector back into proper operation but, also, to ensure that it continues to operate effectively. Therefore, the need for proper maintenance must be put at high priority.

\section{References}

[1] Adegoke, O. S. "Conventional Energy Resources in Nigeria", 1991, In Adegbulugbe and Seriki Ed Energy Issues in Nigeria: Today and Tomorrow.

[2] Ayodele, A. S. "Illegitimate Energy Market Activities in the Nigerian Energy Industry: The Cases of Electricity and Petroleum Products", 1999, Ibadan: Working Paper.

[3] Efuru I. "NIPP Catalyst for Sustainable Power Supply", PHCN News May-August, 2006: Page 5.

[4] Daukoru, E. "Achievements of the Obasanjo Administration in the Energy Sector (1999- 2007)" Sunday Vanguard, February 25, 2007: Page 27.

[5] PHCN News. "Electric Power Reform Law 2005 (V)", PHCN Review January-April, 2006: Pages 16-17.

[6] PHCN News. "Electric Power Reform Law 2005 (VI)”, PHCN Review January-April, 2006: Page 17. 
Advances in Materials and Systems Technologies II doi:10.4028/3-908454-12-3

An Impact Assessment of the Nigerian Power Sector Reforms doi:10.4028/3-908454-12-3.147 